\title{
The Brazilian Constitution: Context, Structure and Current Challenges
}

\author{
Vanice Regina Lirio do Valle*
}

\begin{abstract}
The Brazilian Constitution was enacted over 31 years ago, and it pioneered several constitutional changes in Latin America, in line with a transformational project which was to be achieved through the protection of human rights including socioeconomic rights. Three decades of this constitutional experience have highlighted aspects in which the original design has proven to be too ambitious, and not capable of overcoming political blockages as was originally intended. This Article describes the historical context in which the Brazilian Constitution was drafted and enacted, and discusses in general terms the political structure and the fundamental rights that the constitution provides. These baselines allow the reader to understand the current challenges that the Constitution now faces in the task of regulating a social ambience and collective expectations that are substantially different from those of the late $1980 \mathrm{~s}$ which are synthesized in that same political document. Especial attention is given to judicial control over public policies - a relevant trend in the Brazilian judiciary, which raises much debate concerning its compatibility with the checks and balances principle. As a conclusion, the Article recognizes that the Brazilian Constitution is an institutional success, considering its ability to enable redemocratization, and even to overcome deep political crisis. This should not, however, be enough reason to take its strategy in the human rights field, as a successful one, to be uncritically reproduced in other countries.
\end{abstract}

\section{KEYWORDS}

Brazilian Constitution, Human Rights and the Separation of Powers, Judicialised Constitutionalism, Transformative Commitments and Legislative Inertia, Judicial Review and Public Policy

\section{CONTENTS}

I. Why AdDRESS the BraZILIAN EXPERIENCE?...................................425

II. A Little History: The Brazilian Constituent Assembly .............425

III. The Brazilian Constitutional Structure...............................4428

A. The Brazilian Federalist Model ............................................ 428

i. The Legislative Branch .......................................................429

* Visiting Fellow at the Human Rights Program-Harvard Law School, Doctorate at Gama Filho University. Permanent Professor at the Doctorate Program at UNESA, Rio 


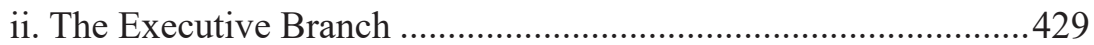

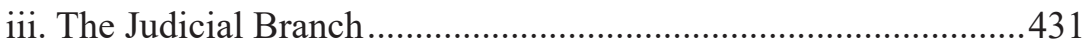

IV. The Constitutional Framework of Human Rights......................433

V. Challenges the Brazilian Constitution Currently Faces.........435

A. Textual Analysis versus Living Constitution...................................435

B. Transformative Commitments versus Legislative Inertia.............. 437

VI. Judicial Review and Public Policies ...............................................438

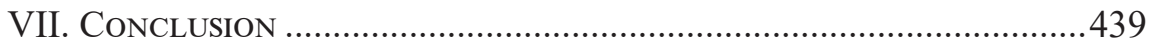




\section{Why AdDRESS THE BRAZILIAN EXPERIENCE?}

Constitutional dialogue, as a learning exercise, starts by understanding the founding commitments that have been articulated in the constitutions of other countries. After all, shared core values might drive the researcher to engage and become involved with other countries' legal systems, which is a basic requirement for comparative legal study. ${ }^{1}$ That understanding can benefit from attention to the historical context in which the constitution was drafted and the social claims to which it was intended to respond. This article describes the historical context in which the Brazilian constitution was drafted and enacted, and comments in general terms on the political structure and fundamental rights that the constitution provides. These baselines enable the reader to understand the current challenges that the constitution now faces.

Foreign constitutional models can offer innovative solutions to shared problems. In an era ruled by globalization, convergence is a recurrent theme that requires a deeper dive into foreign experiences and culture. Against all odds, the Brazilian constitution, which has now been in place for more than 30 years, has greatly exceeded the average 17-year lifespan of such legal documents. ${ }^{2}$ The document offers a generous list of human rights and an immediate application clause, a model that might be appealing as an institutional experiment to countries that share similar social exclusion and economic development challenges. Such an enthusiastic approach, nevertheless, requires a corresponding view of the operational difficulties such constitutional engineering has also created.

The capacity of the Brazilian constitution to coordinate political forces and guarantee its own survival as a general framework for how political decisions can be made comes from its own inbuilt resilience. In the words of Jean de la Fontaine, the Brazilian constitution bends but does not break ${ }^{3}$ and is still standing despite its 105 constitutional amendments. The founding document has also withstood many fiscal and political crises and the impeachment of two democratically elected presidents. Examining the Brazilian experience can provide a better understanding of how a constitution can endure as a source of social commitment and legitimate political power, which is what constitutional dialogue is all about.

\section{A Little History: The Brazilian Constituent Assembly}

In the mid-1980s, Brazil experienced the end of a 20 -year military dictatorship. After a loss of support from civil forces and due to internal military rivalries, ${ }^{4}$ it was

\footnotetext{
Pierre Legrand, Comparative Legal Studies and Commitment to Theory, 58 MoD. L. REv. 262, 263 (1995).

2 See Thomas Ginsburg et al., The Lifespan of Written Constitutions, U. CHI. L. Sch. (Oct. 15, 2009), https://www.law.uchicago.edu/news/lifespan-written-constitutions.

3 "I never break, I merely bend" ("Je plie, et ne romps pas"). JEAN DE La Fontaine, The Oak and the Reed, The Complete Fables of Jean De la Fontaine 25 (Norman R. Shapiro trans., 2007).

4 Jorge Zaverucha, The 1988 Brazilian Constitution and Its Authoritarian Legacy: Formalizing Democracy While Gutting Its Essence, 15 J. ThIRD WorLd Stud. 105, 107 (1998).
} 
evident that the military regime was collapsing and democracy could once again be restored. At that time, the functioning constitution was the one enacted in 1967, significantly altered by several "institutional acts" under the military regime, which had the effect of perverting the original text. These "institutional acts" altered the constitution's provisions as though they were constitutional amendments. The difference was that the "institutional acts" were enacted without the proper constitutional amendment procedure - they were a manifestation of exceptional powers given to the president by the "revolutionary forces."

The redemocratization process called for a new legal framework, a new constitution, to legitimise and regulate the exercise of political power in accordance with democratic principles.. A National Constituent Assembly was summoned in 1985 through the enactment of Constitutional Amendment 26/85, proclaiming that "the members of the Chamber of Deputies and the Federal Senate will meet as one house in a free and sovereign "National Constitutional Assembly."

Installed in 1987, the National Constituent Assembly comprised 559 members of Congress who were elected on November 15, 1986. These congressional representatives were required to serve in both a unicameral constituent assembly and a bicameral ordinary legislature. This double function conditioned the creation of a constitutional framework capable of preventing possible future changes to the governing bodies. After all, those same restrictions, once established, might also challenge representatives' own re-election prospects. There was, moreover, no dominant political force in the National Constituent Assembly, nor was there a previous document to shape the debates. Despite the existence of a draft already prepared by constitutional law scholars, ${ }^{6}$ the proposed draft was rejected to safeguard the assembly's independence in exercising constituent power. ${ }^{7}$ Absent such guiding elements, the new constitution was shaped by and emerged from a process of intense negotiation- "[d]uring that time, the corridors of Congress were an anthropological spectacle," - with interest groups seeking to add provisions to the constitution to suit their own agendas. The less than fortunate outcome of this approach was a very long constitutional text, featuring detailed provisions about peripheral subjects that were included merely because of trade-offs associated with broader political agreements.

5 "The members of the Chamber of Deputies and the Federal Senate will meet as one house in a free and sovereign National Constitutional Assembly on February 1, 1987, at the headquarters of the National Congress. Art. 2. The President of the Federal Supreme Court will convene the National Constitutional Assembly and conduct the session to elect its president. Art. 3 The Constitution will be promulgated after its text is approved, in two discussion and voting sessions, by an absolute majority of the Members of the National Constitutional Assembly." Emenda Constitucional no 26, de 27 de novembro de 1985, Diário Oficial da União [D.O.U.] from Nov. 28, 1985 , arts. $1^{\circ}$ to $3^{\circ}$ (Braz.).

6 Valentina Rita Scotti, Constitutional Amendments and Constitutional Core Values: The Brazilian Case in a Comparative Perspective, 5 Rev. Investig. Const. 59, 66 (2018) (Braz.).

7 There was also a great deal of resistance from the political forces toward the initial constitutional draft due to propositions such as installing a parliamentary regime.

8 Luís Roberto Barroso, Brazil's Unbalanced Democracy: Presidential Hegemony, Legislative Fragility and the Rise of Judicial Power, Luís RoBerto Barroso: Jurisdição Constitucional e Debates Públicos 3, http://www.luisrobertobarroso. com.br/wp-content/uploads/2011/02/Barroso_Brazils-unbalanced-democracy.pdf (last visited Apr.12, 2020). 
Despite considerable popular attention to the work of the National Constituent Assembly and the presence of an unusual clause allowing popular initiatives to be included in the draft, ${ }^{9}$ deliberations about substantive subjects still occurred in a vacuum as part of a bargaining process that took place between elites. Conservative forces were focused mainly on preserving their own influence while progressive representatives fought for the advancement of a political agenda that could respond to social exclusion, viewed by many as the main subject to be addressed by the new constitution. These opposing goals led conservative and progressive forces to embrace distinct strategies.

Conservative forces backed a model of hyper-presidentialism, on the basis that granting extended powers to the executive branch would act as a means to preserve control over substantive political decisions, provided always, of course, that a friendly head of the executive branch could be secured in the future. Progressive forces, on the other hand, promoted an extended list of human rights, which they sought to add to the constitution in the form of clauses that were to be left open textured and ill-defined - a variant application of the known strategy of "deciding not to decide." 10 The assumption was that those rights would be clarified and given content in the future by means of the standard political deliberative process. Progressives also sought to embed constitutional guarantees of access to justice, thus allowing for institutional responses should fundamental rights be denied in the constitution's actual implementation. These two features-hyper-presidentialism and a transformative human rights project - were also common features of other Latin American constitutions at the time, all of which were also attempting to find adequate institutional responses to similar problems.

After an almost two-year period of deliberation, the new Brazilian constitution was promulgated on October 5, 1988, with 245 articles and 70 transitory provisions intended to regulate the transitional process toward the new legal order. Human rights were also successfully embedded in the new constitution. Article 5 lists 77 different fundamental rights and Article 7 lists 34 social rights-all of which were bolstered by an immediate application clause. However, in an attempt to reconcile diverse aspirations, the final text lacked coherence, which has hindered and will continue to hinder its interpretation. ${ }^{11}$ In fact, underdeveloped clauses have required the enactment of 370 distinct new laws - 56 of which necessitated a twothirds parliamentary supermajority. During the promulgation ceremony, Ulisses Guimarães, President of the National Constituent Assembly, asserted that "the Constitution intends to be the voice, the letter, the political will towards change."12 The die was cast.

9 During the deliberative process, 122 popular amendments were proposed, collecting more than $1,000,000$ signatures.

10 Rosalind Dixon \& Tom Ginsburg, Deciding Not to Decide: Deferral in Constitutional Design, 9 InT'L. J. Const. L. 636, 640 (2011).

11 Gary M. Reich, The 1988 Constitution a Decade Later: Ugly Compromises Reconsidered, 40 J. Interamerican StUd. \& World AfF. 5, 6 (1998).

12 Ulisses Guimarães. Discurso de Proclamação da Constituição de 1988. Diario DA Assembleia Nacional Constituinte (Ост. 5Th, 1988) 14380, https://www2.camara. leg.br/atividade-legislativa/plenario/discursos/escrevendohistoria/centenario-deputadoulysses-guimaraes/discurso-de-05101988 (Braz.). 


\section{The Brazilian Constitutional Structure}

Despite the lengthy deliberative process, the Brazilian constitution can be recognized as an institutional success. After all, it allowed for not only the political transition from a military regime to a democratic state but also granted institutional stability for more than 30 years. ${ }^{13}$ In this section, I present the main features of the constitution's structure, and provide the reader with an understanding of the challenges faced by the new Brazilian constitution in the years that followed its adoption .

\section{A. THE BRAZILIAN FEDERALIST MODEL}

The new Brazilian constitution created a federalist state. A decentralized option was almost intuitive in a country with such a large territorial expanse and, further, such a system was already rooted in Brazilian history. ${ }^{14}$ The challenge was to conceive a federalist model fit to create a national government that not only recognized and respected the cultural diversity of its territory but also facilitated local governments to "act in a synchronized manner to avoid a cacophony of conflicting political standards." ${ }^{15}$ The innovative solution was the creation of a three-tier federalist system by creating additional entities called "municípios," municipalities provided with autonomy (the right to self-organization, self-government and self-administration). Those decentralized units have executive competencies in delivering public services and goods. The explanation for this setup was the aim to preserve a locus for the exercise of political power by local leaderships, which is historically very relevant in the political realm. Today, Brazil has 26 states and 5,570 "municípios."

A second distinctive feature of Brazilian federalism is its asymmetry. Despite the formal political autonomy granted to all of the federation's units, there is a strong concentration of legislative competencies in the central government. Asymmetry can also be perceived in the taxation system, which is characterized by the concentration of public revenue in the central government. Despite constitutional clauses establishing mandatory revenue transfers to states and municipalities, the central government receives the lion's share-even though the executive competencies for providing goods and services are decentralized. As a result, there are practical constraints in the proclaimed political autonomy of the subnational federative entities. The central government, for example, frequently interferes in subnational entities through the subterfuge of granting conditional financial support.

13 Dissenting from the understanding of institutional stability allegedly provided by the Brazilian constitution, see Claudio G. Couto \& Rogério B. Arantes, Constitution, Government and Democracy in Brazil, 4 World Pol. SCI. Rev. (2008), claiming that the number of constitutional amendments is evidence that Brazil can be seen as involved in a permanent constitutional convention.

14 Even in its original organization as a colony under Portuguese domination, Brazil was territorially divided into "hereditary captaincies" (capitanias hereditárias).

15 Bruce A. Antkowiak, Contemplating Brazilian Federalism: Reflections on the Promise of Liberty, 43 DuQ. L. Rev. 599, 601 (2005). 


\section{i. The Legislative Branch}

The National Parliament operates as a bicameral model, with 513 federal deputies who are assigned a four-year mandate that coincides with the presidential term, and 81 senators who have an eight-year mandate. The Senate is renewed every four years, as is the Chamber of Deputies - one-third of it in one election and two-thirds in the next election. Commentators have identified a structural problem with Brazil's electoral system related to a constitutional clause that prescribes a minimum and maximum number of representatives for each state. ${ }^{16}$ The formula brings disproportional political representation in the Chamber of Deputies, with heavily populated states, such as São Paulo, being underrepresented and sparsely populated states benefiting from overrepresentation. As the Senate is composed according to the principle of equal representation of states, the result is a disparity in the weight accorded to each vote in the country.

The political system is also highly factionalized, with 33 political parties registered in the Electoral Superior Tribunal. This sort of fragmentation leads to what Brazilian political scientists call "coalition management," meaning that broad and highly negotiated agreements by the president are required in order to advance any legislative initiative. Those negotiations can include offering exchange goods (such as individual budget amendments), coalition goods (such as ministries) and presidential political appointments. ${ }^{17}$ Curiously, this fragmentation has not prevented an extraordinary increase in constitutional amendments across the decades, which, as of writing, total 105.

Coalition management is reflected in the fulfillment of the legislative agenda that the Brazilian constitution proposed in 1988, especially in relation to the regulatory development of fundamental rights. Therefore, there is still a significant gap in the implementation of constitutional clauses - Congress indicates on its official website that 119 constitutional precepts still lack some sort of legislative development. ${ }^{18}$ This clear political deliberative blockage jeopardizes the transformative objectives of the constitution.

\section{ii. The Executive Branch}

In designing the executive branch, the Brazilian constitution chose the path of hyper-presidentialism, not only strengthening the executive powers related to

\footnotetext{
16 "The Chamber of Deputies is composed of representatives of the people, elected, by the proportional system, in each state, territory and in the Federal District.

Paragraph 1. The total number of deputies, as well as the representation of the states and of the Federal District shall be established by a supplementary law, in proportion to the population, and the necessary adjustments shall be made in the year preceding the elections, so that none of those units of the Federation has less than eight or more than seventy deputies." Constituição Federal (Oct. 5th, 1988) art. 45 (Braz.).

17 Sérgio Praça et al., Political Appointments and Coalition Management in Brazil, $3 \mathrm{~J}$. Pol. in Latin Am. 141, 142 (2011).

18 Constituição Federal: Dispositivos Constitucionais Sujeitos à Regulamentação [Federal Constitution: Constitutional Provisions Subject to Regulation], CÂMara dos Deputados (Jan. 21, 2020) (Braz.), https://www2.camara.leg.br/atividade-legislativa/ legislacao/Constituicoes_Brasileiras/regulamentacao/dispositivos (last visited Apr. 20, 2020).
} 
exceptional situations (declarations of war and states of siege) but also providing the branch with semi-legislative powers and close control over administrative units. This design is the result of a tendency in Latin America to accommodate conservative and progressive forces by aggregating rather than synthesizing the aspirations of both sides. ${ }^{19}$ It should be stressed that hyper-presidentialism is more than a unitary executive theory, as it is discussed in the United States, because, in Brazil, it extends presidential powers not only to control administrative entities but also to interfere in activities and deliberations that are typically the purview of other political branches. In Latin America, the concern that the liberal intentions of progressives will be subject to a system of checks and balances mediated by a Parliament dominated by conservatives means that progressives have favored strengthening the executive branch. Therefore, the system of checks and balances has been redesigned to accommodate hyper-presidentialism, which, paradoxically, might represent the same threat progressives sought to eliminate. ${ }^{20}$

There are two significant manifestations of hyper-presidentialism in the Brazilian constitution. The first is the power given to the president to enact "provisional measures" (unilateral decrees with the force of law) about almost any subject within the typical legislative decisional domain. The only constitutional requirement is that the "provisional measure" should be promulgated only in exceptional cases of "relevance and urgency"-a vague expression that, for many years, allowed very loose control, even by the judiciary.

Such "provisional measures" are effective as long as they are published, are applicable for a 60-day period and are renewable, unless Congress concludes its deliberations on the matter. In the initial text of the 1988 constitution, these "provisional measures" were allowed to be perpetually renewed if Congress did not address the matter. Between 1988 and 2002, approximately 6,000 "provisional measures" were issued, including profound economic reforms. ${ }^{21}$ The clearly abusive use of such a quasi-legislative tool led to the approval of Constitutional Amendment $\mathrm{n}^{\circ} 32$, which aims to restrict the scope of such instruments.

A second relevant manifestation of hyper-presidentialism is the power granted to the chief of the executive branch to readdress budgetary resources through "special credits." 22 According to the constitution, Congress, while voting on the annual budget, can enact a general authorization of the reassignment of funds. Executing the Brazilian budget according to legislative deliberation is not entirely mandatory, as some margin of reallocation is left to the president. Within that

19 See generally Roberto Gargarella, Constitutional Changes and Judicial Power in Latin America, in Latin America Since the Left Turn 189 (Tulia G. Falleti \& Emilia A. Parrado eds., 2018).

20 For a historical analysis of how the separation of powers principle has appeared in Brazilian constitutions throughout history, see Keith S. Rosenn, Separation of Powers in Brazil, 47 DuQ. L. Rev. 839 (2005).

21 Luís Roberto Barroso, Brazil's Constitution of 1988 on Its Twenty-First Anniversary, 3 Direitos Fundamentais \& JustiçA 147, 165-166 (2009) (Braz.).

22 "The following are forbidden:

$\mathrm{V}$ - to open a supplementary or special credit without prior legislative authorization and without specification of the corresponding funds;

VI - to reassign, reallocate or transfer funds from one programming category to another or from one agency to another without prior legislative authorization." CONSTITUIÇÃO FEDERAL DE 1988 art. 167 (Braz.). 
margin, the executive branch can transfer revenue destined for ongoing or new public policies or programs through a decree so as to meet the needs of whatever administrative entity the branch sees fit.

In 2015, Constitutional Amendment 85/15 expanded the presidential prerogative related to public funds, allowing the executive branch to readdress, reallocate or transfer funds within science, technology and innovation activities by means of an act without prior legislative authorization. ${ }^{23}$ These budgetary prerogatives allow for a final decision that essentially modifies the democratic deliberation that is supposed to underpin the expenditure of public funds. The power of the purse is always relevant and grants the executive branch an advantageous position allowing it to engage in coalition management with congressional representatives and to eventually interfere in subnational entities frequently involved in fiscal crises. Toward the end of 2019, Congress approved Constitutional Amendment $105 / 19$, which grants congressional representatives the ability to assign funds to subnational entities - one more step in a clear effort by the legislative branch to recover its relevance and overcome the role of being a simple follower of the executive branch's agenda.

\section{iii. The Judicial Branch}

Finally, another relevant feature of the Brazilian constitutional design is its judiciary. Judges in Brazil are mainly selected through public competition. Their office grants them a short tenure after their appointment and provides guarantees such as immovability and stipend irreducibility. Courts are composed mainly of career judges - three-fifths of the total bench in state and federal courts. The other two-fifths are split, one-fifth among members of the public prosecutor's office and one-fifth among lawyers; in both cases, those inducted into the court are chosen by the chief of the executive branch at the federal or state level from a list drawn up by members of his or her own class. Even those who were not originally career judges, once nominated to court, enjoy all the guarantees already mentioned. The constitution gives the judicial branch administrative and financial autonomy with legislative competence in regard to its own budget, institutional prerogatives (including judge guarantees and benefits) and internal organization. The constitutional court in Brazil - the Supreme Federal Court-enjoys the same prerogatives in regard to institutional autonomy. The president has freedom to nominate its eleven justices, the only requirements being that candidates should be over 35 years old, and of "notable juridical learning and spotless reputation" 24 Once nominated by the president, the nominee is subject to senatorial approval, and there is no history of real opposition to any candidate. A member of the Brazilian

23 "Reassigning, reallocating, or transferring funds from one programming category to another may eventually be permitted, within science, technology, and innovation activities, with a view to enabling the outcomes of projects restricted to these functions, by means of an act of the Executive Power, without the prior legislative authorization set forth in item VI of this article" Constituição Federal de OCT. 5TH, 1988 art. 167, ๆ 5 (Braz.).

24 Article 101. The Supreme Federal Court is composed of eleven justices, chosen from among citizens over thirty-five and under sixty-five years of age, of notable juridical learning and spotless reputation. Constituição Federal art. 60, ๆ 4 (Braz.). 
Supreme Federal Court enjoys tenure - at least until the age of 75, when, due to an express constitutional clause, retirement is mandated.

Recourse to litigation in Brazil is a serious issue, with lawsuits reaching the 80 million mark in the entire judicial branch in 2018, according to the National Council of Justice. ${ }^{25}$ That number, despite being high considering that Brazil has a population of 209 million, was celebrated when disclosed as reflecting a reversal in the recent upward trend. This phenomenon is related to the previously mentioned constitutional option to grant access to justice as a means to overcome deficiencies in the institutional system - in short, to prevent the abuse of power. Here, again, one can see constitutional engineering operating through an accumulation of aspirations with the hope that eventual failures by political powers can be corrected by a nonpartisan institutional structure.

Writing on the probable causes of judicialization in Brazil, Barroso points to "the broadening of the constitution's scope, the adoption of both European and American styles of judicial review, as well as the constitutionalization of law." 2623 Brazil's strategy has been to adopt some features of a system based on precedent. Originally, only rulings in abstract constitutionality analysis were binding. The 2015 Brazilian Code of Civil Procedure intended to expand that scope but there is still much debate, with strong internal resistance to a largely precedential system that, according to some, might unduly constrain each judge's prerogative to decide according to the law and the judge's own conscience. The possible effects of a precedential system in such an overloaded judicial branch remain to be seen.

Aside from the general judicialization spread through the entire judicial branch, Brazil is currently dealing with an activist constitutional court. During the first decade of the new constitution, the court was confronted with an unfamiliar and deeply ambitious political document. Justices who had been appointed by the military remained on the bench despite having very little public law experience and little familiarity with transformational constitutions and potential conflicts. Influenced by the political question doctrine, the jurisprudence of the Brazilian Supreme Court remained "quite subservient to what occurred in the legislative or the executive branches." ${ }^{27}$ In the early 1990s, this was not too much of an issue. The main concerns related to consolidating democracy so that matters related to fundamental rights and judicial public policy reviews were not given high priority. At that time, the court dedicated itself mainly to solving federative conflicts.

In the late $1990 \mathrm{~s}$, the scenery changed. The renewal of the court, with the nomination of justices coming from a public law background, contributed to a new perception of the courts' role in ushering in the changes intended by the constitution. At the present time, Brazil is experiencing a representation crisis that most countries in the world, at some point in time, have been distressed by - and the court seems to now be concerned with the possibility of congressional representatives driven

25 Justiça em Números Relatório 2019 [Justice in Numbers 2019], Conselho NaCional De Justiça, Justiça em Números Relatório 2018, (Feb. 12, 2020), https://www.cnj. jus.br/wp-content/uploads/conteudo/arquivo/2019/08/justica_em_numeros20190919. pdf (Braz.) (last visited Apr. 20, 2020).

${ }_{26} \quad{ }^{23}$ Barroso, supra note 20, at 169.

27 Emilio Peluso Neder Meyer, Judges and Courts Destabilizing Constitutionalism: The Brazilian Judiciary Branch's Political and Authoritarian Character, 19 GER. L. J. 727, 757 (2018). 
by minor political interests. Counter-majoritarianism seems to be a relevant feature of providing balance to political practice. Activism is not only practiced by the constitutional court, but it is also defended as a desirable feature with regard to enforcing the foundational document.

One last characteristic of the Brazilian system should be noted to help readers understand the challenges the country is currently facing. The extensive scope of the Brazilian constitution results in its pervasiveness throughout many sectors of life and social relations. Almost every field regulated by law will have a constitutional dimension - through express clauses or by rights or principles that are deemed to be implicit. Brazilian scholars call this phenomenon constitutional pervasiveness. Accordingly, it is the case that lawsuits that challenge the constitutionality of a statute or of an administrative decision are very common. Policing the constitutionality of the law in the Brazilian system is a task shared by all judges and not a special assignment given to particular judges or courts. If many lawsuits can challenge the constitutionality of a particular legal clause and if any judge can proceed with analysis, a system has evolved that allows for the possibility of divergence between rulings. Inequality is always in the shadows, inhibiting the judiciary's ability to secure justice.

\section{The Constitutional Framework of Human Rights}

Finally, yet importantly, a word must be said about the human rights system that was added to the Brazilian constitution. Adding human rights declarations to the constitution was intended to be a mechanism for triggering legislative action for the realization of human rights, and thereby promoting the inclusive society that progressive forces had dreamed of. The strategy was initiated with the proclamation in Article $1^{\circ}$ of the Brazilian state's foundational values, which encompass human dignity and social values such as work and free initiative. The following items were included in the Brazilian constitution with the aim of being carried out as state objectives: building a free, just and compassionate society; eradicating poverty and reducing social inequalities; and promoting general welfare. This commitment to building a social state has now become the subject of much debate. ${ }^{28}$

In addition to an extensive list of expressed human rights, the Brazilian constitution also includes a clause that would require the state to recognize future human rights validated by international law. . The explicit human rights are concentrated in Articles 5 and 7; the former is dedicated to liberty rights, and the latter addresses social rights. Other portions of the Brazilian constitution refer to rights regarding health, social security, environmental protection, child protection, elderly protection and so forth. From these explicit clauses, the Court can also extract implicit human rights, derived from the former, considering the expansive tendency brought by the constitutional commitment with human dignity. All of these rights are bolstered by an immediate application clause contained in Article $5, \S 1^{\circ}$. That specific clause was inserted into the text to repeal a previous

28 See Yaniv Roznai \& Leticia Regina Camargo Kreuz, Conventionality Control and Amendment 95/2016: A Brazilian Case of Unconstitutional Constitutional Amendment, 5 Rev. Investig. Const. 35, 36 (2018) (Braz.). 
understanding that fundamental rights - especially social rights - were merely programmatic rules requiring legislative development as a condition to any sort of application. According to that previous understanding, which prevailed under the 1967 Brazilian constitution (which already had a considerable range of human rights guarantees), if there is a lack of legislative implementation of a given right, that right cannot be pursued, especially via judicial procedures.

The immediate application clause is not unique to the Brazilian constitutionsimilar clauses can be found in other contemporary constitutional texts. The novelty in Brazil's case came at the operational level, when Brazilian scholars turned the understanding of such a clause into a requirement of "immediate efficacy." The change was not merely rhetorical and has deeply transformed the understanding of fundamental rights and the role of courts in granting such rights. The application of a law is about functionality and operation. Efficacy goes further and involves an assessment of results; it aims to consider the real effects as a sort of public initiative in bringing the problem to the forefront. Affirming that a right has application means that it should be operational and operationalised so that institutional inertia or omission will not be an appropriate response. Declaring that a right has efficacy implies not only potential application (therefore justiciability) but also a concrete effect on the public initiatives carried out on the basis of such a right - proving that its application is compatible with the transformational result the constitutionwas intended to bring about.

It is certainly the case that the intention of turning the immediate application clause into immediate efficacy was to bring about change in the sensitive matter of social inclusion and that this was a direct aim of the new constitution. Changing the narrative was perceived as a required strategy ${ }^{29}$, especially considering that the legislative branch showed no willingness to develop social rights legislation. New understandings provide grounds to claim that whenever a fundamental right provided with immediate efficacy is violated - even by the mere non-deliberation about its content by the legislative or executive branch - that right can be judicially claimed. However, the combination of an extensive list of fundamental rights, the immediate efficacy clause and very easy access to the judiciary has resulted in the high levels of judicialization discussed above. Unlike other countries that have dealt with a similar judicialization of socioeconomic rights, Brazilian courts have "not shied away from determining the content of these rights and from issuing mandatory injunctions to compel the state to immediately provide the corresponding goods and services to litigants. ${ }^{\prime 30}$ Judicial control of public policies is considered not only possible but also desirable, as it allows that particular branch to fulfill its duty to guard the constitution. This kind of judicial intervention in public policies can happen at the level of individual lawsuits, of class actions and even in the abstract judicial review of constitutionality. ${ }^{31}$ As long as the enforcement of constitutionally protected human rights is at stake, any judge can provide their own solution to the

$29 \quad$ Ana Beatriz Vanzoff Robalinho Cavalcanti. Brazil in Comparative Perspective: The Legacy of the Founding, and the Future of Constitutional Development. 6 Rev. Investig. Const. 11-33 (2019) (Braz.).

30 Octavio Luiz Motta Ferraz, Harming the Poor Through Social Rights Litigation: Lessons from Brazil, 89 Tex. L. Rev. 1643, 1645 (2010).

31 Vanice Regina Lírio do Valle, Judicial Adjudication in Housing Rights in Brazil and Colombia: A Comparative Perspective, 1 Rev. Investig. Const. 67, 79 (2014) (Braz.). 
alleged threat or harm. The result can be to enhance human rights protection-but different judicial answers to the same constitutional violation lead to inconsistencies which can also reinforce existing inequalities.

These are then, briefly, the relevant components necessary for an initial understanding of the Brazilian constitutional system. One can see that to reach a possible consensus within the National Constituent Assembly - and even before that, considering the intense constitutional amendment process- the Brazilian constitutional text embraces contradictory components. The question that remains, after 30 years of this constitutional experiment, is whether the results match the initial expectations.

\section{Challenges the Brazilian Constitution Currently FACES}

Assessments of the Brazilian constitutional experiment cannot be made with any formal criteria. Nevertheless, after three decades, some strategic options can be evaluated.

\section{A. Textual Analysis versus Living Constitution}

An initial question that arises regarding the Brazilian constitution relates to the success of the textually detailed model-as opposed to a synthetical one. In terms of the length of text of all current constitutions, the Brazilian constitution, with 64.488 words occupies third place in the Comparative Constitutions Project ranking but is closely followed by many other constitutions that exceed 50,000 words. ${ }^{32}$

Historically, as pointed out above, the reason can be attributed to the intention of securing the following items through institutional design: a) the non-abusive exercise of power and b) an answer to the aspirations of numerous interest groups. Explicit norms on states' limitations and duties seem like a relevant constraint on the violation of the core values proclaimed by the constitution itself. Adopting a detailed text was somehow an attempt to clarify obligations. Judicial review, if necessary, would be a simple matter of asserting the constitutional threat or harm, which should be easier, departing from a detailed text. The first observation is that the Brazilian constitution, considering its length, does not differ substantially from others enacted in Latin America during the same time period. ${ }^{33}$

The paradigm is always the United States constitution, compared with which the length of the Brazilian constitution, with its 248 initial articles, appears excessive. The comparison can be deceptive, bearing in mind the fact that at least eight U.S. states have constitutions that surpass the Brazilian constitution in length:

32 Constitution Rankings, Comp. CONST. Project (Apr. 8, 2016), https:// comparativeconstitutionsproject.org/ccp-rankings/ (last visited June 11, 2020). See also http://scocablog.com/californias-constitution-is-not-the-longest/ (last visited Jun. 8, 2020).

33 The Colombian constitution, the first one enacted in Latin America after the Brazilian constitution, contains 380 articles; the Venezuelan constitution, from 1999, contains 350 articles - aside from transitory dispositions; and the Paraguayan constitution, from 1992, contains 291 articles. The trend of lengthier constitutions continued in the rest of Latin America. 
Alabama (369.129), Oaklahoma (98.303), Texas (98.089), Missouri (87.319), Colorado (78.808), Louisiana (77.007), California (74.821), Ohio (68.089) 34

Critics have commented on the deficiencies of the Brazilian constitution more or less from the beginning, but the constant amendment efforts have mainly resulted in adding precepts rather than reducing them. Curiously, even the final part of the constitution, which contains the transitional provisions of the original text - initially destined to fade into oblivion - was amended and expanded. The original 70 precepts have almost doubled, reaching 114 articles at present. The fear that a detailed text might promote rigidity in the constitutional order has been overcome through two distinct strategies: constitutional amendments and a generous, creative space with regard to constitutional interpretation. Amending the constitution is a more intuitive way to ensure that the text corresponds to the current realities of the social and economic conditions of the country. This is a strategy frequently utilized in Brazil - despite the supermajority required for the approval of a constitutional amendment. ${ }^{35}$ Here, again, the coalition management exercised by an overempowered chief of the executive branch will allow the necessary support to be gathered. The number of amendments already approved represents the best evidence that reaching such a majority is not that difficult to achieve.

A second approach that favors the updating of the text, despite the length of time that this would take, is that the inherent risk of disturbing and even distorting the foundational commitments designed by the original text can be mitigated by subjecting the amendments to judicial review whenever they engage the immutable clauses of the Constitution. ${ }^{36}$ The Supreme Federal Court generally exercises its prerogative to declare constitutional amendments unconstitutional, even to the point of applying implicit limitations as a parameter. ${ }^{37}$ It seems to be a common understanding that the dynamics allowing numerous constitutional amendments (subject to judicial review when it comes to immutable clauses) achieve the necessary balance between the original and updated text. In this way institutional stability and the commitment to the protection of human rights have, therefore, truly been achieved albeit at the expense of alterations to the original text. The same cannot be said of what was hoped would be the higher levels of legislative development of constitutional commitments.

34 California's Constitution Is Not the Longest, SCOCABlog (Jun. 24, 2017), http:// scocablog.com/californias-constitution-is-not-the-longest/.

35 "The proposal shall be discussed and voted upon in each House of the National Congress, in two readings, and it shall be considered approved if it obtains in both readings, threefifths of the votes of the respective members." Constituição Federal DE OCT. 5TH, 1988 art. 60, $\uparrow 2$ (Braz.).

36 "No proposal of amendment shall be considered which is aimed at abolishing: I - the federative form of State;

II - the direct, secret, universal and periodic vote;

III - the separation of the Government Powers;

IV - individual rights and guarantees." Constituição Federal art. 60, ๆ 4 (Braz.).

37 Yaniv Roznai, Unconstitutional Constitutional Amendments-The Migration and Success of a Constitutional Idea, 61 Am. J. Comp. L. 657, 665 (2013). 


\section{B. TRANSFORMative CommitmentS VERSUS LEGISLATIVE INERTIA}

History demonstrates that the National Constituent Assembly intended to embed within the new constitution a transformative project to overcome social exclusion. Though the hope was that consensus about legislative content and states' obligations would emerge by means of the political deliberative process, fundamental rights and their own guarantees entered the constitutional text through open textured clauses, the precise scope and application of which is unclear and provoke considerable disagreement. Providing a list of fundamental rights in the constitutional text could avoid a thorny debate about the theoretical foundations for that sort of special state protection, but would not eliminate the difficult decisions about who should benefit from such rights and what kind of content should be recognized within those rights. ${ }^{38}$

Apparently, members of the National Constituent Assembly had forgotten that regulating socioeconomic rights will always involve distributional choices and trade-offs, which may prove problematic for congressional representatives. The unavoidable distributive decisions associated with a broader debate in social public policies can be difficult, especially in a country with such profound social, geographic and economic differences as those found in Brazil. Defining distributional criteria requires prioritization, and in a country in which the state has been presented as a "universal insurer," that sort of prioritization is politically costly. On the other hand, leaving things undecided opens up the possibility for a judicial resolution of the matter, transferring the burden of the decision to another agent. If a bad choice is made or if there is collateral damage coming from the ruling, the judge can always be blamed.

Clear evidence that the legislative branch feels comfortable with simply proclaiming vague socioeconomic rights - avoiding the challenging operation of defining the limits of such rights - is seen in the expansion of constitutional amendments contained in Article 6 of the Brazilian constitution. Additions include the right to housing (Constitutional Amendment 26/00), the right to food (Constitutional Amendment 64/10) and the right to transportation (Constitutional Amendment 90/15) - none of which include any detail related to content and none of which have been regulated since their inclusion. The initial response provided by the constitutional framework in respect of legislative or executive inertia cannot overcome the strategical political evaluation carried out by the legislative branch. Goods or services might be granted to a lucky plaintiff, but this will be at the expense of universality. ${ }^{39}$ Inequality was present at the beginning of the constitution's drafting, when social exclusion was considered the evil to be fought. The result of leaving rights' decisions to judges to be decided on the basis of their assessments of the merits of individual cases does nothing to remedy that inequality which remains very much present to this day.

38 Fundamental rights in the Brazilian constitution are expressed with different levels of indeterminacy, requiring, when there is vagueness, a broader definition of the content of the constitution; see Vanice Regina Lirio do Valle, Enforcing Socio-Economic Rights Through Immediate Efficacy: A Case Study of Rio de Janeiro's Right to Housing, 25 Tul. J. INT'L \& COMP. L. 1 (2016).

39 Octavio Luiz Motta Ferraz, The Right to Health in the Courts of Brazil: Worsening Health Inequities? 11 Health Hum. Rights 33 (2009). 
Moreover, in the Brazilian experience, an even worse outcome has presented itself, namely the commoditization of such rights. Whenever scarcity is unsurmountable, judges who feel the urge to grant immediate efficacy to fundamental rights can simply rule that some award of money should be granted to the plaintiff, turning a plea for human rights protection into a sort of a perverted tort lawsuit. ${ }^{40}$ The conclusion is that granting justiciability to human rights violations as a constitutional response to the political blockage of a transformative project, although ingenious, is not satisfactory. Aside from fostering a continuing pattern of non-deliberation from the legislative branch - after all, one can always address oneself to a judge - judicial intervention, whenever it happens, deviates from the equitable and universal granting of the claimed rights. Even constitutions face practical limitations when it comes to changing political practice.

\section{Judicial Review and Public Policies}

Expanding the scope of judicial review to encompass the merits of public policies devoted to giving effect to fundamental rights might sound an appealing answer to the difficult challenge of overcoming political blockages in the legislative or executive branches. Judicial reviews in other countries with constitutional grants of socioeconomic rights have been criticized exactly because they do not provide a concrete definition of the goods and services to be delivered. Nevertheless, the key to success for the Brazilian solution remains elusive.

The objection to broad judicial review based on the judiciary's lack of proper institutional capacities is well known. Designing public policies requires not only specific technical knowledge but also a factual understanding of the various components of a specific social problem. It also requires a dynamic follow-up on the preconditions and results associated with the initial strategic choice. None of these features is present in regard to the judicial function. Lawsuits are designed to look backward, decode the presented litigation and present a single definitive and correct solution. Public policy, by contrast, is a tool to plan for the future, proposing an approach to solve an identified problem - a strategy that can only be proven to be intrinsically wrong or require improvements as time goes by. Law seeks stability; public policies coexist with dynamics.

Law deals with certainty. A judge searches for the one legal and right solution. Technicians designing public policies know that in the legal realm, nothing is certain; even science does not claim to provide certainty. Public policy designers aim for the best possible solution-even if it is really second best. Advancing through terra incognita can result in a ruling that is dissociated from the reality in which the public policy at stake operates, rendering the intervention useless. Fearing that exact risk, a ruling can also merely validate the public policy at stake, providing a comfort zone for the executive branch, which can continue doing exactly what has been done before and nothing more. This creates a distorted situation in which the

40 Vanice Regina Lírio do Valle, Judicialization of Socioeconomic Rights in Brazil: Mercantilization of the Fundamental Rights as a Deviance in Rights Protection (January 18, 2014). Paper presented in the 3rd YCC Conference - American Society of Comparative Law, at the Lewis \& Clark University, Portland, Oregon, in April 2014. Available at SSRN: https://ssrn.com/abstract=2511648/ (last visited Apr. 20, 2020). 
judge, aiming to enforce human rights, will promote, or at least allow, regression in the fulfillment of such a right.

Transposing the moral claims at the basis of the human rights discourse into the language of law is a strategy in the long-term fight for the protection of human dignity. ${ }^{41}$ Law becomes a tool - not the only one and not the best one, but simply one more tool in this historic fight. This is why addressing human rights conflicts mainly within the domain of the law - even with the supposedly reassuring presence of the all-mighty judiciary - can never promote the desired social transformation. Aside from that intrinsic difference, allowing judicial control over public policies brings, as already mentioned, a major risk of inequality. A judicial response to that sort of claim might be influenced by the judge's view about the judicial function itself (more activist or deferential to the other branches' decisions) and by the ruler's understanding of the fundamental right at stake. In such a complex context, transferring those distributive decisions to the judiciary is not only an anomaly, considering the ordinary functions assigned to each power branch, it is also incentive for the legislative power to abdicate its main task - to represent its constituents, even (if not especially) during difficult distributive choices.

The initial appraisal of the judicial control of public policies is losing support in Brazil. A concern with the need for coherent and uniform approaches on the part of the judiciary in respect of recognition of fundamental rights is leading the National Council of Justice to discuss issues such as the judicialization of health rights, creating a forum to explore strategic possibilities. The deferential judicial approach in regard to the regulatory choices of the administrative state is also being used as a possible criterion for recalling all branches to their own original functions and responsibilities. The enforcement of human rights through the judiciary is clearly not the right option for promoting structural transformation. This is the lesson learned in Brazil.

\section{CONCLUSION}

Drafting a constitution is never easy. Historical and political forces constrain not only the moment in which a constitution is written but also the period of its application. The constitution, operating through the branches of power, can affect people's lives and social relations in ways very different from those envisioned by the country's constituents. Each nation's experience with its own constitution teaches us a little bit about the gap between constitutional expectations and constitutional possibilities.

The Brazilian constitution, as already mentioned, can be considered a successful experiment, given that it consolidated the redemocratization movement and led the country in the direction of badly wanted institutional stability. The constitution provided the response that Brazilian culture required at the time. This does not mean that the constitution is a model to be reproduced uncritically in other places.

One can especially learn from the well-intentioned experience of the social transformation project, which was added to the constitution as an afterthought and

41 Stuart A. Scheingold, The Politics of Rights: Lawyers, Public Policy and Political Change 63-71 (1974). 
by way of democratic concession but which lacked the conceptual clarity that would have compelled the political branches to give it real effect. Hope was its basis; it should have been the emphasis in the deliberation in Parliament. Reassigning the transformation project to the judiciary was never the constituents' intention-and is not bringing about the hoped for change. Denying reality rarely works-lesson learned! 